\title{
CLUSTERS, INNOVATIONS AND ENERGY EFFICIENCY: IF RELANTIONSHIP COULD BE TRACED
}

In the presented paper specific aspects of clusters' role in energy security enhancement are being discussed. An assumption of role of clusters as driving force of smart growth with respective effect on service sector development is being raised and discussed. It is claimed, that smart growth will contribute to expansion of service sector; i.e. will accelerate the processes observed now. The analytical part of the paper is devoted to long range forecasting (until year 2050) of energy intensity of service sector in selected countries of different development. The aim of such forecasting is to reveal if energy intensities in service sector will diminish and converge as result of innovative processes affected by clustering of stakeholders, which are business companies, universities, state and society. We claim that clustering of listed stakeholders through technology and consumption culture transfer affect energy intensity change trends in service sector and push it down. We argue that interrelationships among clusters, smart growth and energy security (through diminishing energy intensity in service sectors of differently developed countries) could be traced. We assume that indicated interrelationship does not depend of level of countries' development; anyway less developed European countries benefit more from clustering phenomenon.

Keywords: clusters, energy security, innovations, service sector, sustainable development.

DOI: $10.21272 / \mathrm{mmi} .2017 .2-35$

Introduction and background. Discussion about the role of clusters in regional development has become contemporary classics. When we recall this classics, as the first association comes Porter, one of the most prominent scientist from Harvard Business School. In order to pay a tribute to this wellknown scientist, let us start discussion about clusters from his definition of a cluster. According him "clusters are geographic concentrations of interconnected companies and institutions in a particular field. Clusters encompass an array of linked industries and other entities important to competition. They include, for example, suppliers of specialized inputs such as components, machinery, and services, and providers of specialized infrastructure. Clusters also often extend downstream to channels and customers and laterally to manufacturers of complementary products and to companies in industries related by skills, technologies, or common inputs. Finally, many clusters include governmental and other institutions - such as universities, standards-setting agencies, think tanks, vocational training providers, and trade associations - that provide specialized training, education, information, research, and technical support [40]. What is peculiar about Porter's approach towards clusters' impact assessment, that he emphasizes exceptionally positive effect for their members and outsiders: Let us go through main highlighted insights provided by the author in Harvard Business School Review of year 1998. According the prominent author, „a cluster allows each member to benefit as if it had greater scale or as if it had joined with others without sacrificing its flexibility" cluster members feel "peer pressure, pride, and the desire to look good in the community"..."at the intersection of clusters, insights and skills from various fields merge, sparking new businesses"..."clusters offer a constructive way to change the nature of the dialogue between the public and private sectors" [35].

After these insights were formulated, a lot of papers on clusters have been published and economic policies fostering clusters implemented. In the research a focus has shifted into analysis of clusters composition; attempts to measure efficiency and even benchmark performance of different clusters can be noticed [2, 16, 21, 47, 48]. Technology transfer phenomenon now is mainly associated with clusters' activity [49]. Technology transfer is associated to innovations of various origins, i.e. both, technological and social innovations. The role of both ones in the process of sustainable innovative development is highly emphasized in resent literature $[1,5,7,9,11,12,17-19,23,25,27,29,30-34,36,38,39,41]$. 
If to discuss areas, in which clusters are being found, we need to admit, that there are no specific areas, which could be indicated as especially characteristic for clustering activities. Nowadays clusters emerge in wide array of areas; actually in any area or field of activity clusters can emerge naturally or be established. Not an area of activity here is of importance; value added, which can be created by cluster members - that is what matters, and triggers clustering activities.

We focus our research to area of energy use - efficiency and intensity- factors, which impact sustainable economic development and are widely discussed in contemporary literature (e.g. [3, 6, 22, $40,43,44])$. Since our target is as well energy security, basing on considerations provided above, let us try to find out what is clusters' role in energy security enhancement, if any. Let us provide our argumentation how we see clusters' impact on energy security.

At first, let us clarify what we mean by energy security in this context. Energy security can be perceived in very different ways, depending on what stakeholder - public or professional - expresses his/her opinion (e.g. [8, 14, 24, 26, 28, 42, 45-47]). In the context of our research, in which possible effect of clustering phenomenon is discussed, we use energy security concept as synomimous to energy efficiency. Further in this paper we will try discuss tendencies of change of energy intensities in service sectors in selected countries, meaning that energy intensity, ultimately, is joint result of energy efficiency and behavioural patterns in energy consumption. After this clarification we can move with our research further. We raise an assumption that clustering phenomenon due to its innovative potential serves as driving force for smart growth. Despite smart growth can be observed in any sector of economics [36, $43,44,47-51$ ] the most susceptible sector for innovations remains service sector [13]. Technological innovations, and more frequently, social innovations affect fast development of service sector. Dynamics of service sector development is provided below in Figure 1.

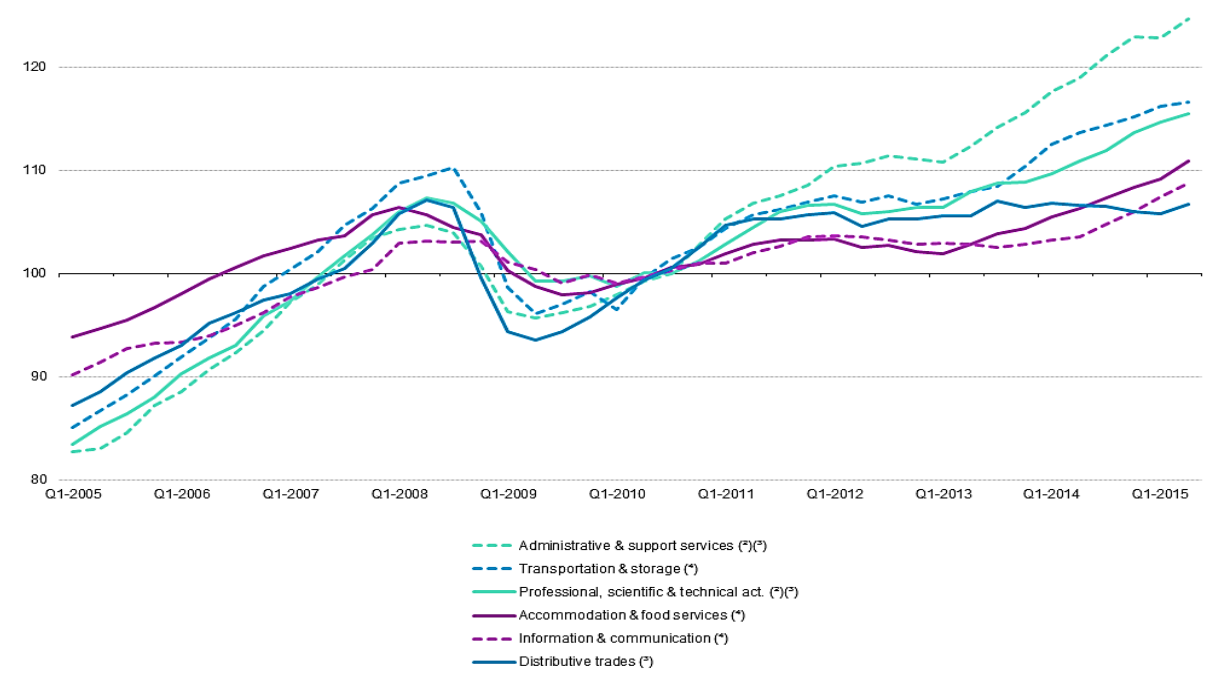

(1) Seasonally and working-day adjusted

(") As required by the STS Regula: $2005-09$ : estimates

(') 2005-09 and 2015. : 2 stimates.
Source: Eurostat (online data codes: sts_trtu_q and sts_setu_q)

Figure 1 - Development of service sector in Europe during the last decade [15]

Coverage of analyzed problematics in the latest literature. Before we go to forecasting results let us clarify if other scientists are interested in analysis of relationships between clustering phenomena and 
energy security. Let us look at the latest literature on the topic. At first we searched Thomson Reuters Web of Science database using keywords "clusters" and "energy efficiency". Results are provided in Figure 2.

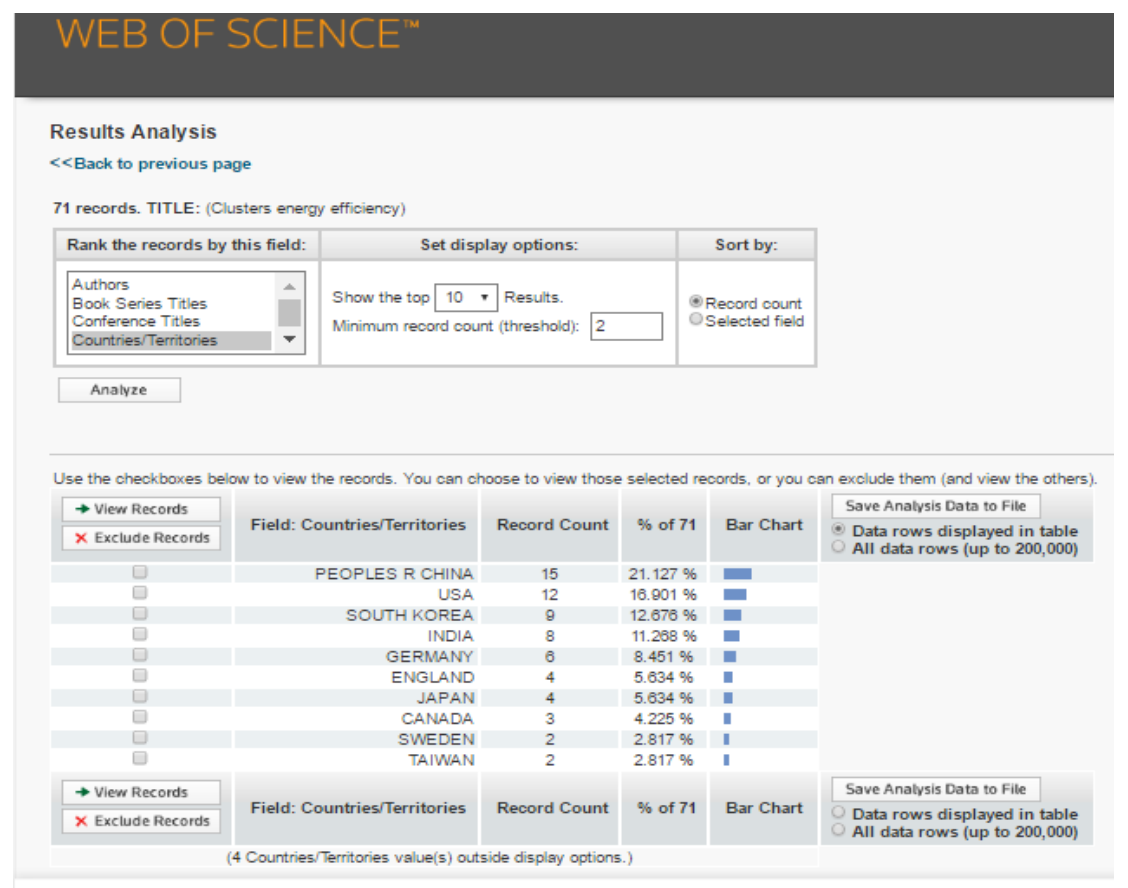

Figure 2 - Results of sources' search in Thomson Reuters Web of Science database using keywords "clusters" and "energy efficieny" (authors' inquiry in database Web of Sciences)

The major contributor to the selected topic is China. That could be easily explained by population size in this country. Another message, which is being sent by the clip from Thomson Reuters webpage (same the Fig. 1) is that, the topic embracing clusters and energy efficiency issues is existent but still in very early stage of development. The discussion mainly spins around smart grids and IT systems. We encountered one paper, which tackled energy efficiency and clustering phenomena in such energy intensive industry as chemical industry.

This approach does not embrace variety of clustering actors, which is emphasized in our study. Here clustering phenomena is limited to concentration of simiclar technologically related productive facilities.

Let us examine SCOPUS database using the same keywords. The search results are provided in Figure 3. Data about publishing on the provided topic suggests that the research interests in it is increasing, because number of papers devoted to interrelation between clustering phenomenon and energy consumption is sharply raising. The published papers in SCOPUS database similarly like in Web of Science Core Collection database are mostly devoted to energy efficiency in IT: the search results indicated that during 2012- 2016 year there were 888 papers containing key-words "clusters" and "energy efficiency"; 566 out of them were attributed to computer science, 376 to engineering, 95 to mathematics, 54 to energy and 47 to physics and astronomy. Provided information, despite its sporadic nature, is sufficient to verify that research is devoted to relationship between clustering phenomena and energy efficiency is emerging. 


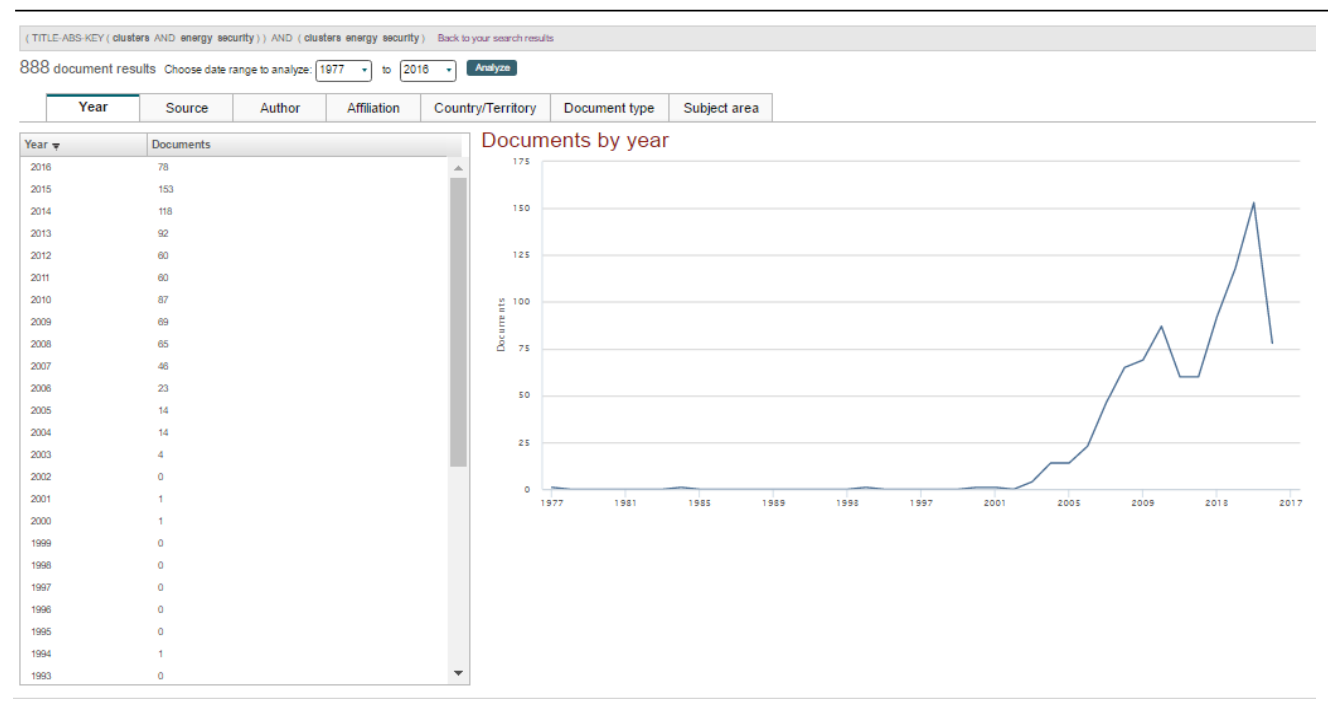

Figure 3 - Results of sources' search in Elsevier SCOPUS database using keywords "clusters" and "energy efficiency" (Source: authors' inquiry in database SCOPUS)

Long-range forecasting of energy intensities of service sectors in selected countries. Let us look at energy intensities forecasted for service sectors until year 2050 for selected countries. For forecasting we will use the Long-range Energy Alternatives Planning System (LEAP), is a widely-used software tool for energy policy analysis and climate change mitigation assessment developed at the Stockholm Environment Institute [20].

Methodology. In order to reveal long-term tendencies of energy intensities change of service sectors of selected countries we need to make certain assumptions, which are necessary for any mathematical modelling or forecasting. Since currently available statistical data are already incorporated into LEAP software, we need to decide what changeable indicators to choose. There is possibility to make the following assumptions: pattem of change of GDP growth, overall economy's energy intensity change; population growth, economy structure change, specifically, changes of value added growth in agriculture, services, industry, manufacturing and construction. Besides it is possible to set Gini index, transportation mode shares (air, rail, and road) and electric generating capacity (solar, geothermal, hydro, wind, nuclear, thermal, tide and wave). Hence, we see that a lot of options for multivariate modeling are provided. In order to set one or another conditions we need to provide respective argumentation. Only in that case obtained scenarios would have appropriate value for decision makers while choosing one or another economic policy. In our research we have purpose to observe trends in energy intensity of service sector of selected countries in case we maintain current conditions. Therefore our forecasting is based on current trends, and we use ceteris paribus assumption, as it was already indicated. Of course, there are research limitations, since conditions can change and then our forecasting would not provide sufficiently precise trends. Anyway, we believe that modelling should be the next step, which followed after trends based on ceteris paribus assumption is analyzed and interpreted.

We select the following countries: the best developed European countries are represented by Germany and France, and comparatively less developed countries in our empirical research are represented by Check Republic, Lithuania, Latvia and Bulgaria. By selecting the two groups of countries and representatives for those groups we aimed to check if consistent patterns can be found, and if we can conclude that some general tendencies could be distinguished and explained. The results of forecasting are provided in Figure 4. 
М. Тваронавісіене. Кластери, інновації та енергоефективність: чи є взаємозв'язок

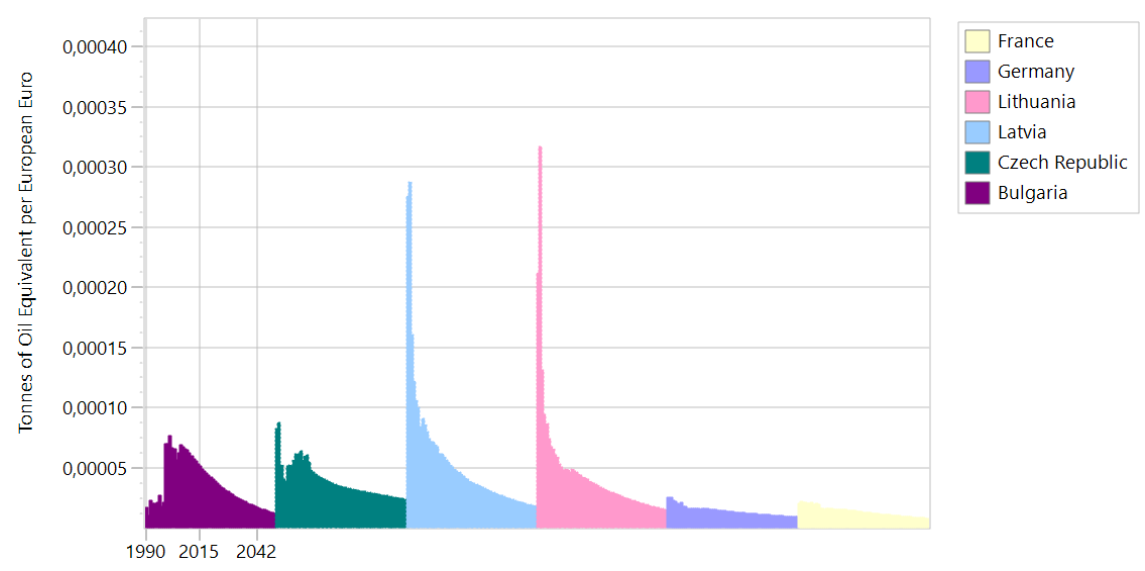

Figure 4 - Energy intensities of service sector in selected countries; year 1990-2050 (Source: authors, obtained using software LEAP)

The following generalities could be revealed: the first, energy intensities in both more developed European countries - France and Germany - are considerably lower than in all countries representing group of less developed European countries. The observation holds for the whole considered period, i.e. from year 1990 to year 2050. We can claim that observed trends let us reveal one consistent pattern: better developed countries due to technological advance perform much better in energy efficiency area, therefore their energy intensity, as resulting indicator, much better. Here we can assume that behavioral patterns in energy consumption can be characterized by one of the two formulated statements: the first, behavioral patterns are oriented to energy stewardship, either, the second, behavioral patterns are not sequent oriented to energy stewardship. In the latter case, technological innovations remain the major driver conditioning increasing energy efficiency, and therefore diminishing energy intensity.

Let us take a closer look at behavior of service sector and its energy intensity in Lithuania (Figures 5 and 6) and Germany (respectively Figures 7 and 8).

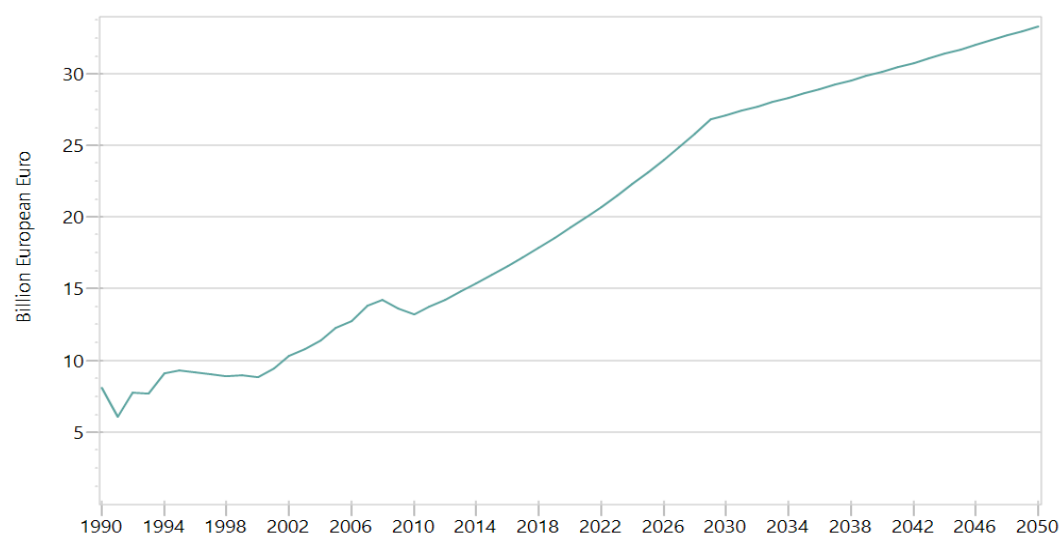

Figure 5 - Expansion of service sector in Lithuania until year 2050

(Source: authors, obtained using software LEAP) 


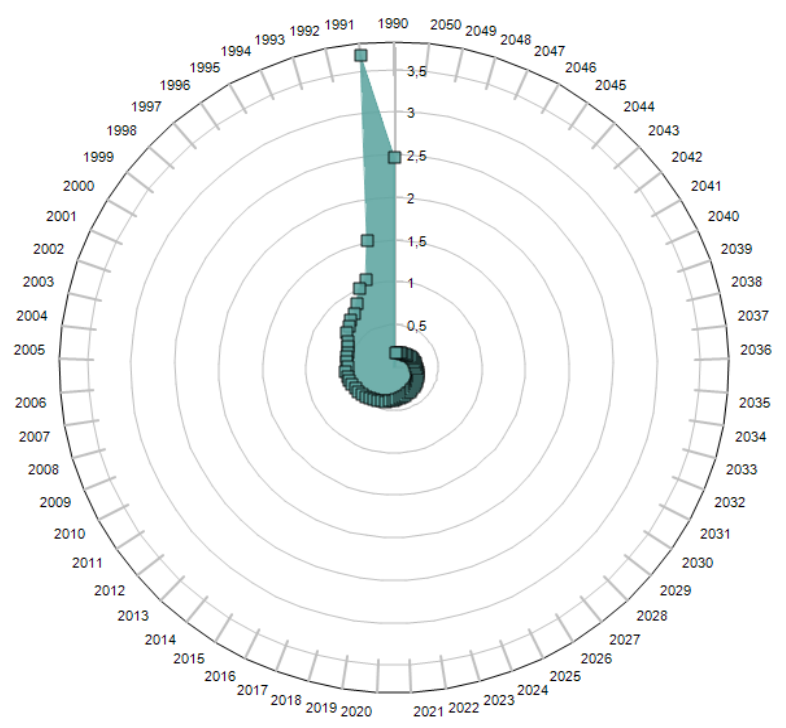

Figure 6 - Energy intensity of service sector in Lithuania; year 1990-2050 (Source: authors, obtained using software LEAP)

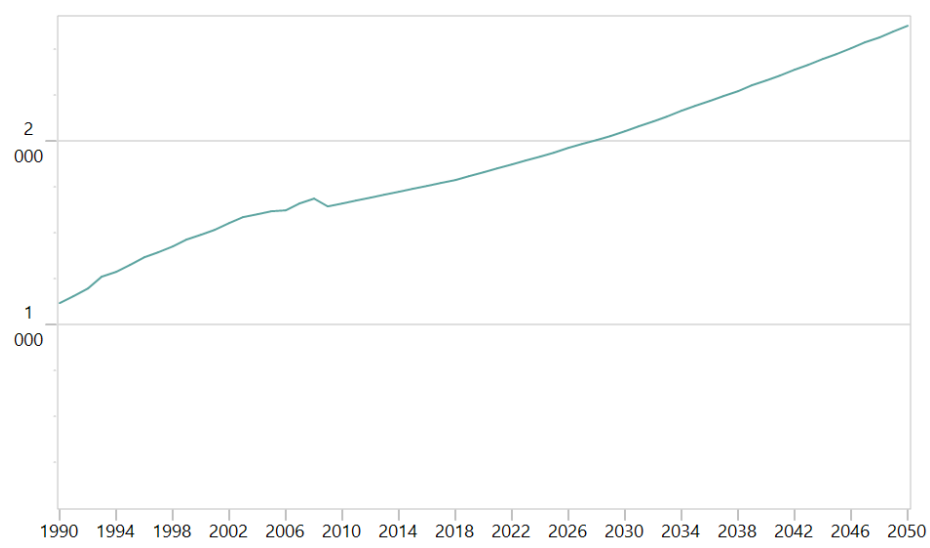

Figure 7 - Expansion of service sector in Germany until year 2050 (Source: authors, obtained using software LEAP)

It is observed the same general tendency of service sector expansion. Energy intensities of service sector in long term change in different way: in Lithuania diminishing is more intensive; while in Germany energy intensity since approximately year 2020 stabilizes and further diminishes very gradually. We can conclude that at currently achieved level of technology Germany does not have much potential to diminish energy intensity further, unless behavioral changes, oriented to energy stewardship were implemented. Here social innovations resulted from clustering of different stakeholders could be employed. Returning to Lithuania (the same holds for other countries similar to Lithuania according their 
level of development), it has to be noted that both - technological innovations, and social innovations for energy efficiency will remain of importance for couple of decades, at least.

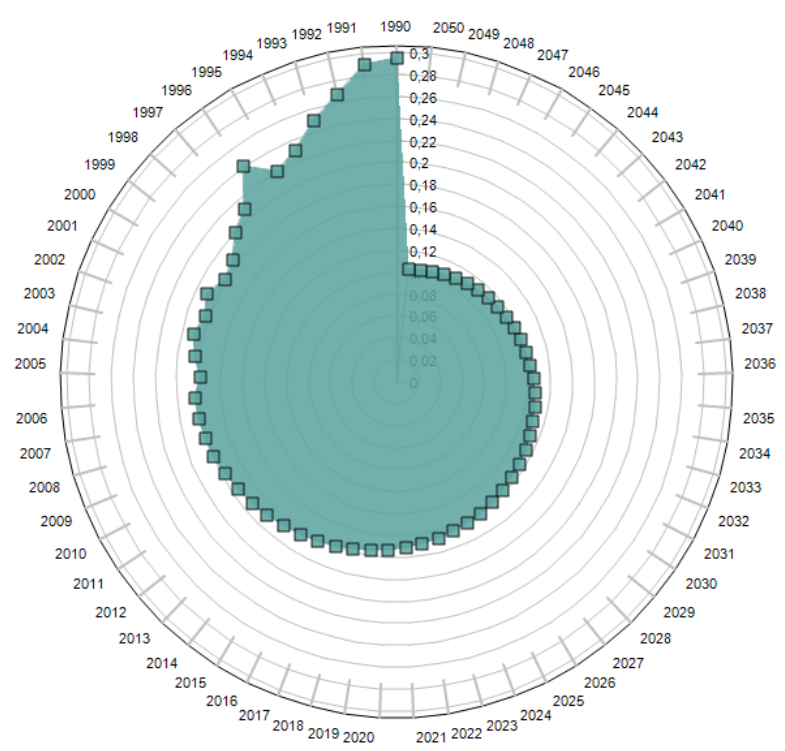

Figure 7 - Energy intensity of service sector in Germany; year 1990-2050 (Source: authors, obtained using software LEAP)

To generalize the obtained results it should be emphasized, that energy intensity of service in better developed European countries will diminish very gradually during the whole forecasted period, until year 2050. As concerns comparatively less developed European countries (including Lithuania) their progress in indicated are will be more intensive, while in year 2050 they would still be lagging behind currently better developed countries, such as e.g. Germany. Basing on obtained results, the following insight can be formulated: there is room for impacts of tacit factors, which can push energy intensity down both, in more developed and, especially, less developed European countries. If we admit that forecasted energy intensity level of service sector, e.g. in Germany, is used as a benchmark, what could be achieved in ceteris paribus conditions, then difference between e.g. Lithuanian respective energy intensity and Germany's benchmarked energy intensity indicate reserve for improving energy intensity, especially when Germany demonstrates such good results having rather intensively expanding service sector. Lagging behind could be eliminated via various tools. Clustering is one of the important means of technology transfer, and cultural change. Therefore role of clusters, we believe, cannot be overestimated in such area as energy security enhancement.

Conclusions. As the result of presented research the following insights are formulated:

- clusters affect smart growth, especially in service sector, which is highly susceptible for innovations, both technological and social;

- service sector in European countries is expanding, energy intensity is gradually diminishing and ceteris paribus will diminish until year 2050 both in developed, and less developed European countries. Nevertheless, less developed countries still have higher potential to diminish energy intensity in service sector, the conclusion stemming from forecasting results of more developed 
countries (e.g. Germany);

- energy intensity is dependent on tangible (patents, technology) and intangible (e.g. clusters affecting behavioral change) factors. Since absolute level of energy intensity remains much higher in less developed European countries, clustering due of its resulting effect is more beneficial for less developed European countries.

Questions for further discussion: it still remain unclear how to evaluate impact of technological innovations on energy intensity diminishing and how to estimate role of cultural change. Currently technologies are under intensive elaboration (e.g. [1, 4, 10, 27, 33, 34]); it is not clear how effective would be their implementation with clusters taking active part and without clusters involved. On the other hand, if new technologies appear, that should be taken into account in further mathematical forecasting and modelling. There is still a lot of room for further mathematical modelling by setting different initial conditions other than ceteris paribus approach.

1. Ahmed, A., McGough, D., \& Mateo-Garcia, M. (2017). Testing innovative technologies for retrofitting: Coventry University as a living lab, Journal of Security and Sustainability Issues, 4 (3), 257-270. DOI: http://dx.doi.org/10.9770/jesi.2017.4.3S(2).

2. Akhmadeev, B., Manakhov, S. (2015). Effective and sustainable cooperation between start-ups, venture investors, and corporations, Journal of Security and Sustainability Issues, 5 (2), 269-284. DOI: http://dx.doi.org/10.9770/jssi.2015.5.2(12).

3. Balitskiy, S., Bilan, Y., \& Strielkowski, W. (2014). Energy security and economic growth in the European Union, Journal of Security and Sustainability Issues, 4 (2), 123-130. DOI: http://dx.doi.org/10.9770/jssi.2014.4.2(2).

4. Barberis, S., Roncallo, F., \& Traverso, A. (2017). Towards innovative district energy management: a case study with stochastic renewable generators, Entrepreneurship and Sustainability Issues, 4 (3), 294-309. DOI: http://dx.doi.org/10.9770/jesi.2017.4.3S(5).

5. Baronienè, L., \& Žirgutis, V. (2016). Management decisions for sustainable development: medical software case study, Entrepreneurship and Sustainability Issues, 4 (2), 129-145. DOI: http://dx.doi.org/10.9770/jesi.2016.4.2(2).

6. Baublys, J., Miškinis, V., Konstantinavičiūtè, I., \& Lekavičius, V. (2015). Energy efficiency as precondition of energy security. Journal of Security and Sustainability Issues, 4 (3), 197-208. DOI: http://dx.doi.org/10.9770/jssi.2015.4.3(1).

7. Boonyachut, S. (2016). Sustainability of community's entrepreneurship: case of floating market at Ladmayom. Entrepreneurship and Sustainability Issues, 4 (2), 211-219. DOI: http://dx.doi.org/10.9770/jesi.2016.4.2(8).

8. Corneliu, M.; \& Tamošiūnienè, R. (2015). Modern approaches in quantifying economic security. Case study of Estonia, Latvia, Lithuania and Republic of Moldova, Journal of Security and Sustainability Issues, 4 (4), 596-610. DOI: http://dx.doi.org/10.9770/jssi.2015.4.4(2)S

9. Crosbie, T., Short, M., Dawood, M., \& Charlesworth, R. (2017). Demand response in blocks of buildings: opportunities and requirements. Entrepreneurship and Sustainability Issues, 4 (3), 271-281. DOI: http://dx.doi.org/10.9770/jesi.2017.4.3S(3).

10. Daher, E., Kubicki, S., \& Guerriero, A. (2017). Data-driven development in the smart city: Generative design for refugee camps in Luxembourg, Entrepreneurship and Sustainability Issues, $4(3)$, 364-379. DOI: http://dx.doi.org/10.9770/jesi.2017.4.3S(11).

11. Dlugoborskytè, V., Norvilaitè, V., Petraitè, M. (2015). Creativity and innovation management: team performance peculiarities, Entrepreneurship and Sustainability Issues, 3 (1), 25-38. DOI: http://dx.doi.org/10.9770/jesi.2015.3.1(2)T.

12. Dobele, L., Grinberga-Zalite, G., \& Kelle, L. (2015). Sustainable economic development: scenarios for promotion of social innovation in Latvia, Journal of Security and Sustainability Issues, 5 (2), 149-158. DOI: http://dx.doi.org/10.9770/jssi.2015.5.2(2).

13. Dudzevičiūtè, G., Mačiulis, A., \& Tvaronavičienè, M. (2014). Structural changes of economies: Lithuania in the global context, Technological and economic development of economy, 20 (2), 353-370. DOI: http://dx.doi.org/10.3846/20294913.2014.915597.

14. Espona, R. J. de. (2016). Energy Security, resilience and Critical InfrastructureProtection: Spanish Puertollano Refinery crisis case, Journal of Security and Sustainability Issues, 5 (3), 323-328. DOI: http://dx.doi.org/10.9770/jssi.2016.5.3(2).

15. Eurostat (n.d.). Retrieved from http://ec.europa.eu/eurostat/data/browse-statistics-by-theme.

16. Fuschi, D., \& Tvaronavičienè, M. (2016). A network based business partnership model for SMEs management, Entrepreneurship and Sustainability Issues, 3 (3), 282-289. DOI: http://dx.doi.org/10.9770/jesi.2016.3.3(5).

17. Gandini, A., Garmendia, L., \& San Mateos, R. (2017). Towards sustainable historic cities: mitigation climate change risks, Entrepreneurship and Sustainability Issues, 4 (3), 319-327. DOI: http://dx.doi.org/10.9770/jesi.2017.4.3S(7).

18. García-Fuentes, M. A., \& de Torre, C. (2017). Towards smarter and more sustainable regenerative cities: the REMOURBAN model, Entrepreneurship and Sustainability Issues, 4 (3), 328-338. DOI: http://dx.doi.org/10.9770/jesi.2017.4.3S(8).

19. Gasparènienè, L., Remeikienè, R., Sadeckas, A., \& Ginevičius, R. (2016). Level and sectors of digital shadow economy: the case of Lithuania, Entrepreneurship and Sustainability Issues, 4 (2), 183-197. DOI: http://dx.doi.org/10.9770/jesi.2016.4.2(6).

20. Heaps, C.G., (2016). Long-range Energy Alternatives Planning (LEAP) system. [Software version: 2017.0.4] Somerville, 


\section{М. Тваронавісіене. Кластери, інновації та енергоефективність: чи є взаємозв'язок}

MA, USA : Stockholm Environment Institute. Retrieved from https://www.energycommunity.org

21. Ignatavičius, R., Tvaronavičienè, M., \& Piccinetti, L. (2015). Sustainable development through technology transfer networks: case of Lithuania, Journal of Security and Sustainability Issues, 4 (3), 261-267. DOI http://dx.doi.org/10.9770/jssi.2015.4.3(6).

22. Jefremov, V., \& Rubanovskis, A. (2015). Towards a sustainable Latvian energy resources and energy markets in the context of the EU, Journal of Securityand Sustainability Issues, 4 (3), 552-563. DOI: http://dx.doi.org/10.9770/jssi.2015.4.3(5)S.

23. Lace, N., Buldakova, N., \& Rumbinaitè, G. (2015). Organizational creativity as a driving force for company's innovative development, Entrepreneurship and Sustainability Issues, 3 (2), 137-148. DOI: http://dx.doi.org/10.9770/jesi.2015.3.2(2)

24. Leonavičius, V., Genys, D., \& Krikštolaitis, R. (2015). Public perception of energy security in Lithuania, Journal of Security and Sustainability Issues, 4(4), 311-322. DOI: http://dx.doi.org/10.9770/jssi.2015.4.4(1).

25. Lynch, P., Power, J., Hickey, R., \& Messrevey, T. (2017). Business model strategies: Flexibility trade in emerging low voltage distribution networks, Entrepreneurship and Sustainability Issues, 4 (3), 380-391. DOI: http://dx.doi.org/10.9770/jesi.2017.4.3S(12).

26. Miškinis, V., Baublys, J., Lekavičius, \& V., Morkvènas, A. (2013). New Changes in Lithuanian Energy Sector, Journal of Security andSustainability Issues, 2(3), 15-28. DOI: http://dx.doi.org/10.9770/jssi.2013.2.3(2).

27. Mouraud, A. (2017). Innovative time series forecasting: auto regressive moving average vs deep networks, Entrepreneurship and Sustainability Issues, 4 (3), 282-293. DOI: http://dx.doi.org/10.9770/jesi.2017.4.3S(4).

28. Narula, K., \& Reddy, B.S. (2015). Three blind men and an elephant: The case of energy indices to measure energy security and energy sustainability, Energy, 80: 148-158.

29. Oates, M., Melia, A., \& Ferrando, V. (2017). Energy balancing accross cities: Virtual Power Plant prototype and iURBAN case studies, Entrepreneurship and Sustainability Issues, 4(3), 351-363. DOI: http://dx.doi.org/10.9770/jesi.2017.4.3S(10).

30. Oganisjana, K., \& Surikova, S. (2015a). Social innovation in the promotion of sustainable development of the contemporary Latvian society, Journal of Security and Sustainability Issues, 5 (2), $249-258 . \quad \mathrm{DOI}$ http://dx.doi.org/10.9770/jssi.2015.5.2(10).

31. Oganisjana, K., Surikova, S., \& Laizāns, T. (2015b). Factors influencing social innovation processes in Latvia: qualitative research perspective, Entrepreneurship and Sustainability Issues, 3 (2), 186-197. DOI: http://dx.doi.org/10.9770/jesi.2015.3.2(6).

32. Olaniyi E. O, \& Reidolf, M. (2015). Organisational innovation strategies in the context of smart specialization, Journal of Security and Sustainability Issues, 5 (2), 213-227. DOI: http://dx.doi.org/10.9770/jssi.2015.5.2(7).

33. Passerini, F., Sterling, R., Keane, M., Klobut, K., \& Costa, A. (2017). Energy efficiency facets: innovative district cooling systems, Entrepreneurship and Sustainability Issues, 4 (3), 310-318. DOI: http://dx.doi.org/10.9770/jesi.2017.4.3S(6).

34. Perfido, D., Raciti, M., Zanotti, C., Chambers, N., Hannon, L., Keane, M., \& et al. (2017). Towards sustainable water networks: automated fault detection and diagnosis, Entrepreneurship and Sustainability Issues, 4 (3), 339-350. DOI: http://dx.doi.org/10.9770/jesi.2017.4.3S(9)

35. Porter, M.E. (1998). Clusters and the New Economics of Competition, Havard Business Review https://hbr.org/1998/11/clusters-and-the-new-economics-of-competition.

36. Prause, G. (2015). Sustainable business models and structures for industry 4.0, Journal of Security and Sustainability Issues, 5 (2), 159-169. DOI: http://dx.doi.org/10.9770/jssi.2015.5.2(3).

37. Prause, G. (2016). E-Residency: a business platform for Industry 4.0?, Entrepreneurship and Sustainability Issues, 3(3), 216-227. DOI: http://dx.doi.org/10.9770/jesi.2016.3.3(1).

38. Rosha, A., \& Lace, N. (2015). Sustainable development of organizations: coaching for innovation accelerating, Journal of Security and Sustainability Issues, 5 (2), 171-180. DOI: http://dx.doi.org/10.9770/jssi.2015.5.2(4).

39. Štitilis, D., Pakutinskas, P., \& Malinauskaitè, I. (2016). Preconditions of sustainable ecosystem: cyber security policy and strategies, Entrepreneurship and Sustainability Issues, 4 (2), 174-182. DOI: http://dx.doi.org/10.9770/jesi.2016.4.2(5)

40. Strielkowski, W. (2016). Entrepreneurship, sustainability, and solar distributed generation, Entrepreneurship and Sustainability Issues, 4(1), 9-16. DOI: http://dx.doi.org/10.9770/jesi.2016.4.1(1).

41. Traversari, R., Den Hoed, M., Di Giulio, R., \& Bomhof, F. (2017). Towards sustainability through energy efficient buildings design: semantic labels, Entrepreneurship and Sustainability Issues, 4 (3), 243-256. DOI: http://dx.doi.org/10.9770/jesi.2017.4.3S(1).

42. Tvaronavičienè, M. (2012). Contemporary perceptions of energy security: policy implications, Journal of Security and Sustainability Issues, 1 (4), 235-247. DOI: http://dx.doi.org/10.9770/jssi.2012.1.4(1).

43. Tvaronavičienè, M. (2016a). Entrepreneurship and energy consumption patterns: case of hoseholds in selected countries, Entrepreneurship and Sustainability Issues, 4 (1), 74-82. DOI: http://dx.doi.org/10.9770/jesi.2016.4.1(7).

44. Tvaronavičienè, M. (2016b). Start-ups across the EU: if particular tendencies could be trace, Entrepreneurship and Sustainability Issues, 3 (3): 290-298. DOI: http://dx.doi.org/10.9770/jesi.2016.3.3(6).

45. Tvaronavičienè, M., Šimelytè, A., \& Lace, N. (2014). Sustainable development facets: exporting industrial sectors from inside, Journal of Security and Sustainability Issues, 3 (4), 37-44. DOI: http://dx.doi.org/10.9770/jssi.2014.3.4(4).

46. Tvaronavičienè, M., \& Černevičiūtè, J. (2015). Technology transfer phenomenon and its impact on sustainable development, Journal of Security and Sustainability Issues, 5 (1), 87-97. DOI: DOI: http://dx.doi.org/10.9770/jssi.2015.5.1(7).

47. Tvaronavičienè, M., Mačiulis, A., Lankauskienè, T., Raudeliūnienè, J., \& Dzemyda, I. (2015). Energy security and 
sustainable competitiveness of industry development, Economic research = Ekonomska istraživanja, 28 (1), 502-516. DOI: http://dx.doi.org/10.1080/1331677X.2015.1082435.

48. Tvaronavičienè, M., Razminienè, K., \& Piccinetti, L. (2015). Cluster efficiency study through benchmarking, Entrepreneurship and Sustainability Issues, 3 (2), 120-128. DOI: http://dx.doi.org/10.9770/jesi.2015.3.2(0).

49. Tvaronavičius, V., \& Tvaronavičiene, M. (2008). Role of fixed investments in economic growth of country: Lithuania in European context, Journal of Business Economics and Management, 9 (1), 57-64.

50. Vasiliūnaitè, R. (2014). Sustainable development: methodological approaches toward issues, Journal of Security and Sustainability Issues, 3 (3), 69-75. DOl: http://dx.doi.org/10.9770/jssi.2014.3.3(6).

51. Vosylius, E., Rakutis, V., \& Tvaronavičienè, M. (2013). Economic growth, sustainable development and energy security interrelations, Journal of Security and Sustainability Issues, 2 (3), 5-14. DOI: http://dx.doi.org/10.9770/jssi.2013.2.3(1).

M. Тваронавісіене, PhD, професор, кафедра економіки та управління підприємствами, Вільнюський технічний університет ім. Гедімінаса (м. Вільнюс, Литва); кафедра управління, Литовська військова академія імені генерала Йонаса Жямайтіс (м. Вільнюс, Литва)

Кластери, інновації та енергоефективність: чи є взаємозв'язок

У цій статті обговорюються конкретні аспекти ролі кластерів в підвищенні енергетичної безпеки. Піднімається і обговорюється припущення про роль кластерів в якості рушійної сили інтелектуального зростання з відповідним впливом на розвиток сектора послуг. Стверджується, що розумне зростання сприятиме розширенню сфрери послуг; тобто прискорить процеси, що спостерігаються. Аналітична частина статті присвячена довгостроковому прогнозуванню (до 2050 року) енергоємності сектора послуг в окремих країнах різного розвитку. Мета такого прогнозування - виявити, чи буде зменшуватися і сходитися інтенсивність енергоспоживання в секторі послуг в результаті інноваційних процесів, що торкаються кластери зацікавлені сторони, які є бізнес-компаніями, університетами, державою і суспільством. У статті автори стверджують, що кластеризація перерахованих учасників за допомогою передавання технологій і культури споживання впливає на тенденції зміни енергоємності в секторі послуе і підштовхує їх. Також в статті відмічено, що можна простежити взаємозв'язок між кластерами, розумним зростанням і енергетичною безпекою (за рахунок зниження енергоємності в секторах послуг в різних розвинених країнах). Передбачається, що зазначена взаємозв'язок не залежить від рівня розвитку країн; у будь-якому разі, менш розвинені європейські країни більше виграють від явища кластеризаиії.

Ключові слова: кластери, енергетична безпека, інновації, сектор послуг, сталий розвиток.

M. Тваронависиене, PhD, профессор, кафедра экономики и управления предприятиями, Вильнюсский технический университет им. Гедиминаса (г. Вильнюс, Литва); кафедра управления, Лито́вская вое́нная акаде́мия имени генерала Йонаса Жямайтиса (г. Вильнюс, Литва)

\section{Кластеры, инновации и энергоэффективность: есть ли взаимосвязь}

В этой статье обсуждаются конкретные аспекты роли кластеров в повышении энергетической безопасности. Поднимается и обсуждается предположение о роли кластеров в качестве движущей силы интеллектуального роста с соответствующим воздействием на развитие сектора услуд. Утверждается, что разумный рост будет способствовать расширению сферы услуг; то есть ускорит наблюдаемые процессы. Аналитическая часть статьи посвящена долгосрочному прогнозированию (до 2050 года) энергоемкости сектора услуг в отдельных странах разного развития. Цель такого прогнозирования - выявить, будет ли уменьшаться и сходиться интенсивность энергопотребления в секторе услуг в результате инновационных процессов, затрагиваемых кластерами заинтересованных сторон, которые являются бизнес-компаниями, университетами, государством и обществом. В статье авторы утверждают, что кластеризация перечисленных участников посредством передачи технологий и культуры потребления влияет на тенденции изменения энергоемкости в секторе услуг и подталкивает их. Также в статье замечено, что можно проследить взаимосвязь между кластерами, умным ростом и энергетической безопасностью (за счет снижения энергоемкости в секторах услуг в разных развитых странах). Предполагается, что указанная взаимосвязь не зависит от уровня развития стран; во всяком случае, менее развитые европейские страны больше выигрывают от явления кластеризации.

Ключевые слова: кластеры, энергетическая безопасность, инновации, сектор услуг, устойчивое развитие.

Отримано 14.03.2017 p. 